\title{
Shell allometry and length-mass-density relationship for Mytilus edulis in an experimental food-regulated situation
}

\author{
Marianne Alunno-Bruscia' ${ }^{1}$, Edwin Bourget ${ }^{2}$, Marcel Fréchette $^{3, *}$ \\ ${ }^{1}$ IFREMER, Laboratoire Conchylicole de Méditerranée, Chemin de Maguelone, 34250 Palavas-les-Flots, France \\ ${ }^{2}$ Faculté des sciences et de génie, Pavillon Alexandre-Vachon, Université Laval, Québec, QC, G1K 7P4, Canada \\ ${ }^{3}$ Institut Maurice-Lamontagne, Ministère des Pêches et Océans Canada, C.P. 1000, Mont-Joli, QC, G5H 3Z4, Canada
}

\begin{abstract}
We examined the influence of food availability and population density on the morphometry and shell length body mass relationship of Mytilus edulis. Mussels were reared in the laboratory for 22 mo at 8 different density levels in 11 chambers supplied with natural seston at 2 different concentrations. This allowed us to assess separately the effects of food availability and mussel density. The shell length/width and shell height/width ratios were affected by food, density and time. Mussels tended to be narrower (flatter) at high density and at low food level. Therefore, narrow shells could result from reduced food concentration in high density situations without implying physical interference. Shell mass was also influenced by both food and density levels, but to a lesser extent than tissue dry mass. In contrast with soft tissue mass, shell mass increased significantly for all food and density levels between October 1995 and October 1996. The elevation of the shell length-body mass-population density relationship was lower at low food availability. The slope of the tridimensional relationship, however, increased with decreasing food level, indicating apparent asymmetric competition for all food-density treatments pooled together. This pattern, however, is misleading because mussels obviously cannot interact among chambers. Since the slopes of length mass relationships are used in predicting self-thinning exponents in space-regulated situations, it follows that self-thinning exponents in mussels should be sensitive to background food level, thus limiting the use of self-thinning relationships for resolving factors regulating growth.
\end{abstract}

KEY WORDS: Mussels $\cdot$ Shell allometry $\cdot$ Food regulation $\cdot$ Length-mass-density relationship $\cdot m-N$ curve

\section{INTRODUCTION}

Mollusks, like most organisms, exhibit progressive changes in their relative proportions with increasing body size. These allometric changes in relative shell proportions reflect constraints imposed by optimization of the geometry of internal transport networks (West et al. 1997, Banavar et al. 1999). Responses to environmental conditions may add to these constraints

${ }^{*}$ Corresponding author.

E-mail: frechettem@dfo-mpo.gc.ca (see Seed 1980). For instance, in mussels reared in high-density situations the relationship between length $(L)$ and mass $(m)$ expressed by the allometric equation $m=\mathrm{a} \cdot L^{\mathrm{b}}$, with slopes $\mathrm{b}>3$ and as high as 4 (i.e. positive allometry; see La Barbera 1989, for a complete definition) as compared to expected values $\leq 3$ (Schepartz 1980, Peters 1983, West et al. 1997), has been interpreted as a response to high-density conditions instead of a reflection of an ontogenetic process (Fréchette et al. 1992).

Indeed, of the various ecological factors known to influence shell shape, population density seems to play 
one of the most important roles in Mytilus edulis (Seed 1968, 1973, Brown et al. 1976). High population density has generally been reported to lead to elongated shells in mussels (Coe 1946, Lent 1967, Brown et al. 1976, Richardson \& Seed 1990), although extreme deformation may be observed in some cases (Bertness \& Grosholz 1985). Individual shape is also affected by population density in oysters (Tanita \& Kikuchi 1957, Chinzei et al. 1982), clams (Ohba 1956, Cigarria \& Fernandez 1998) and tunicates (Paine \& Suchanek 1983), for instance. Perhaps the most spectacular effect of high population density on individual shape in benthic suspension feeders is found in conspicuous hummocks formed by high-density barnacle populations (Bertness et al. 1998). Crowding is usually understood as implying physical interference. Manipulations of population density in some infaunal bivalves, however, have shown no evidence of physical interference (Peterson 1982). This is consistent with food depletion in dense bivalve beds and with individual growth being food regulated (Wildish \& Kristmanson 1984, Fréchette \& Bourget 1985a,b). Therefore the effect of high population density on mussel shape (e.g. Seed 1968) could result either from food regulation, physical interference or their interaction. In the following we use the commonly held definition of 'crowding' as involving physical interference only, as opposed to food depletion. We use the term ' $N$-effects' to indicate either food depletion or crowding.

In the present investigation, we attempted to assess the respective roles of food depletion and crowding in $\mathrm{N}$-effects on blue mussel morphology. We examined shell shape and the growth allometry of shell and soft tissue in Mytilus edulis according to different food and population density treatments. Firstly, we investigated if differences in shell morphology occurred among density groups and food treatments. Secondly, we examined growth in shell mass in relation to growth in soft tissue. And thirdly, we tested whether the tridimensional shell length-body mass-population density relationship varied with food concentration and time. The present contribution complements an earlier study examining the joint effects of density and biomass on the growth and survival of $M$. edulis (Alunno-Bruscia et al. 2000), the aid of which was to determine the shape of the biomass-density $(B-N)$ relationship and to test the self-thinning theory in mollusks.

\section{MATERIALS AND METHODS}

Experimental design. The design was the same as in an experimental study of the relationship between body size and population density in Mytilus edulis (Alunno-Bruscia et al. 2000): 8 density groups $(8,16$,
$24,40,48,64,72$ and 80 mussels per 11 chamber, hereafter labelled $N 8, N 16, N 24, \ldots, N 80)$, plus 2 additional empty 11 chambers $(N O)$, to monitor food level, were arranged orthogonally with 2 food treatments over a 22 mo period, roughly from 1995 to 1996. Each fooddensity-year combination contained 3 replicate chambers. In December 1994, 4224 mussels (shell length, $L=1.9$ to $2.1 \mathrm{~cm}$; average ash-free dry mass of soft tissues, $m=0.037 \pm 0.008 \mathrm{~g}$ ) obtained from a mussel farm in Îles-de-la-Madeleine (Québec, Canada) were stocked into 120 identical $1 \mathrm{l}$ experimental chambers at the Maurice-Lamontagne Institute (Mont-Joli, Québec, Canada). Mussels in half of the 11 chambers were collected in October 1995 and the other half in October 1996.

The mussels were fed 2 food concentrations: high food ( $\mathrm{HF}=100 \%$ of non-filtered seawater), and low food ( $\mathrm{LF}=\mathrm{HF} / 3$ ), which was achieved by mixing $~ 30 \%$ non-filtered seawater with $\sim 70 \%$ filtered seawater in 2 head tanks. In both cases, seawater was pumped from the nearby St. Lawrence estuary. Filtered seawater was obtained by filtering through a 80 to $120 \mu \mathrm{m}$ mesh quartz filter. Typical total seston concentration in this region is low, on the order of $1 \mathrm{mg} \mathrm{l}^{-1}$ (Kranck 1979, Demers et al. 1987, Fréchette \& Grant 1991), except on occasional windy days (Demers et al. 1987, AlunnoBruscia et al. 2000). Summer water temperature typically reaches 10 to $12^{\circ} \mathrm{C}$, and drops to about $-1^{\circ} \mathrm{C}$ in winter; annual water salinity averages 25 . From late October to mid-May, only filtered seawater was available, and mussels were fed dried Spirulina sp. (Spirulina Microfine, Argent Chemical Laboratories) at 2 concentrations adjusted to a 3:1 LF/HF ratio (for more details, see Alunno-Bruscia et al. 2000). Seawater was distributed by gravity from head tanks to the 11 chambers at a flow rate of $0.60 \pm 0.06 \mathrm{l} \mathrm{min}^{-1}$. It was assumed that water in the chambers was well mixed, though this assumption may not have been fully met. The chambers were cleaned weekly to remove sedimented materials, or whenever wind events resulted in significant amounts of resuspended sediments entering the chambers.

Mussels were divided among cells within cages, and cages within $1 \mathrm{l}$ chambers, to minimize interference between individuals (Okamura 1986). Each 11 chamber (11.2 cm diam., $14.0 \mathrm{~cm}$ high) contained 2 identical cylindrical Vexar cages $(10.2 \mathrm{~cm}$ diam., $4.5 \mathrm{~cm}$ high, $0.7 \mathrm{~cm}$ mesh). Cages were divided into 4 identical cells by 2 perpendicular polyethylene walls. Each cell was stocked with $1,2,3,5,6,8,9$ or 10 mussels, depending on the density treatment. At the beginning of the experiment, cages within 11 chambers were randomly assigned an initial 'up' or 'down' position, which was changed on a regular basis to minimize position effects on mussel growth. 
Sampling and biological observations. Sampling was conducted on 12 dates between December 1994 and October 1996 (for more details, see Alunno-Bruscia et al. 2000). In the present study we focus on biological observations from 12 to 14 October 1995 (mid-experiment) and 1 to 2 October 1996 (end of experiment). Individual mussel size was defined through 3 linear shell dimensions: shell length $\left(L, \mathrm{~mm}_{;}\right.$maximum antero-posterior axis), height $\left(H, \mathrm{~mm}_{i}\right.$ maximum dorsoventral axis) and width $\left(W, \mathrm{~mm}_{\text {; }}\right.$ maximum lateral axis), measured with a vernier caliper to the nearest $0.1 \mathrm{~mm}$. Live mussels were counted $(N)$ and returned to their cells, whereas dead mussels were measured and removed. Individual ash-free dry mass $(m, g)$ and shell mass $\left(m_{\mathrm{SH}}, g\right)$ were determined in October 1995 by sacrificing mussels from half of the $1 \mathrm{l}$ chambers, and in October 1996 after harvesting the remaining individuals. Mussels were frozen at $-18^{\circ} \mathrm{C}$ for later determination of soft tissue and shell mass with a Mettler AE 163 balance to the nearest $0.0001 \mathrm{~g}$. Ash-free dry mass was obtained by computing the difference between dry body mass, measured after thawing, removing the byssus and drying at $70^{\circ} \mathrm{C}$ for $72 \mathrm{~h}$, and its ash mass after combustion at $450^{\circ} \mathrm{C}$ for $24 \mathrm{~h}$.

Statistical analyses. Shell morphology: To investigate changes in shell morphology, i.e. the relationship between the linear shell dimensions, we conducted a MANOVA on ln-transformed individual $L / H$ and $L / W$ ratios, with density, food and year as fixed factors, and replicate chambers as the error term. $L / H$ and $L / W$ exhibited a significant departure from univariate (Kolmogorov-Smirnov $D$-statistic: $\mathrm{p}<0.01$ ) and bivariate normality (Mardia skewness and kurtosis: $\mathrm{p} \ll 0.001$; \%MULTNORM SAS macro, SAS 1989). Deviation from multivariate normality, however, has only a small effect on Type I error (e.g. Stevens 1992). The assumption of equivalence of the variance-covariance matrices was not met $(p \ll 0.001)$. This should not be of great importance when observed probability levels for $F$-statistics are highly significant, but in case of marginal significance levels, results should be interpreted with some caution (Hand \& Taylor 1987). Because the ratio $H / W$ was not independent of $L / H$ and $L / W$, lntransformed individual $H / W$ was analyzed in a separate 4-way mixed ANOVA with food, density and year as fixed factors, and with replicates nested in the combination of food $\times$ density $\times$ year. Since normality and heteroscedasticity assumptions were not met after lntransformation, we conducted an ANOVA on ranked data. Departures from the assumptions underlying the usual ANOVA were of no consequence since parametric and non-parametric statistics gave the same results. Finally, a posteriori comparisons (Student-NewmanKeuls' test, SNK) allowed us to identify specific differences among food treatments, density levels and years.
Shell mass growth and comparison with soft tissue growth: Average individual shell mass $\left(m_{\mathrm{SH}}\right)$ in October 1995 and 1996 was plotted against $N$ after transformation to its natural logarithm in order to build $m_{\mathrm{SH}^{-}}-N$ curves. To be consistent with $m-N$ curves previously published under food-driven self-thinning conditions (Alunno-Bruscia et al. 2000), chambers exhibiting no mortality were eliminated from the analysis. The $m_{\mathrm{SH}^{-}}$ $N$ curves were tested by covariance analysis (Sokal \& Rohlf 1981). Differences in growth of shell mass $\left(m_{S H}\right)$ relative to soft tissue mass $(m)$ among food-density groups were investigated by calculating the ratio $\mathrm{m} / \mathrm{m}_{\mathrm{SH}}$. A 4 -way mixed ANOVA was carried out to test for the influence of food, density and year on the lntransformed individual ratio $\mathrm{m} / \mathrm{m}_{\mathrm{SH}}$. The normality and homoscedasticity assumptions were satisfied.

Tridimensional length-mass-density relationship: Changes in the shell length-body mass-population density relationship of mussels between food treatments and years were tested by multiple regression analyses (Stevens 1992) for 2 data sets separately: (1) only chambers with mortality and (2) all chambers. The multiple regression model related individual flesh mass $(\ln m)$ or shell mass $\left(\ln m_{\mathrm{SH}}\right)$ to 4 independent variables: individual shell length $(\ln L)$, final density $\left(\ln N_{\mathrm{F}}\right)$, food level (Food) and year (Year). Food level and year were included in the analysis as binary variables following Neter et al. (1985). Length was centered, i.e. $\ln L-\overline{\ln L}$, to overcome multicollinearity between the $Y$-intercept and $\ln L$. The regression model was written as:

$$
\begin{aligned}
& \ln m \text { or } \ln m_{\mathrm{SH}}= \\
& \quad\left(\beta_{0}-\beta_{1} \times \overline{\ln L}-\beta_{5} \times \overline{\ln L} \times \text { Food }-\beta_{7} \times \overline{\ln L} \times \text { Year }\right) \\
& \quad+\beta_{1} \times \ln L+\beta_{2} \times \ln N_{\mathrm{F}}+\beta_{3} \times \text { Food }+\beta_{4} \times \text { Year } \\
& \quad+\beta_{5} \times \ln L \times \text { Food }+\beta_{6} \times \ln N_{\mathrm{F}} \times \text { Food }+\beta_{7} \times \ln L \times \text { Year } \\
& \quad+\beta_{8} \times \ln N_{\mathrm{F}} \times \text { Year }+\beta_{9} \times \text { Food } \times \text { Year }+\varepsilon
\end{aligned}
$$

The corresponding parameters $\beta_{i}$ for the other interaction terms are not shown because they were not significantly different from 0 . $t$-tests were performed to test for significance of the parameters $\beta_{i}$, thus enabling comparison of slopes and intercepts between food levels and years (Neter et al. 1985). Assumptions of multiple regression analysis were examined, i.e. independence, normality and homoscedasticity of the residuals. No severe violations were found.

\section{RESULTS AND DISCUSSION}

\section{Shell morphology}

Average ratios of shell length/height $(L / H)$, length/ width $(L / W)$ and height/width $(H / W)$ were plotted against population density for both food treatments in 


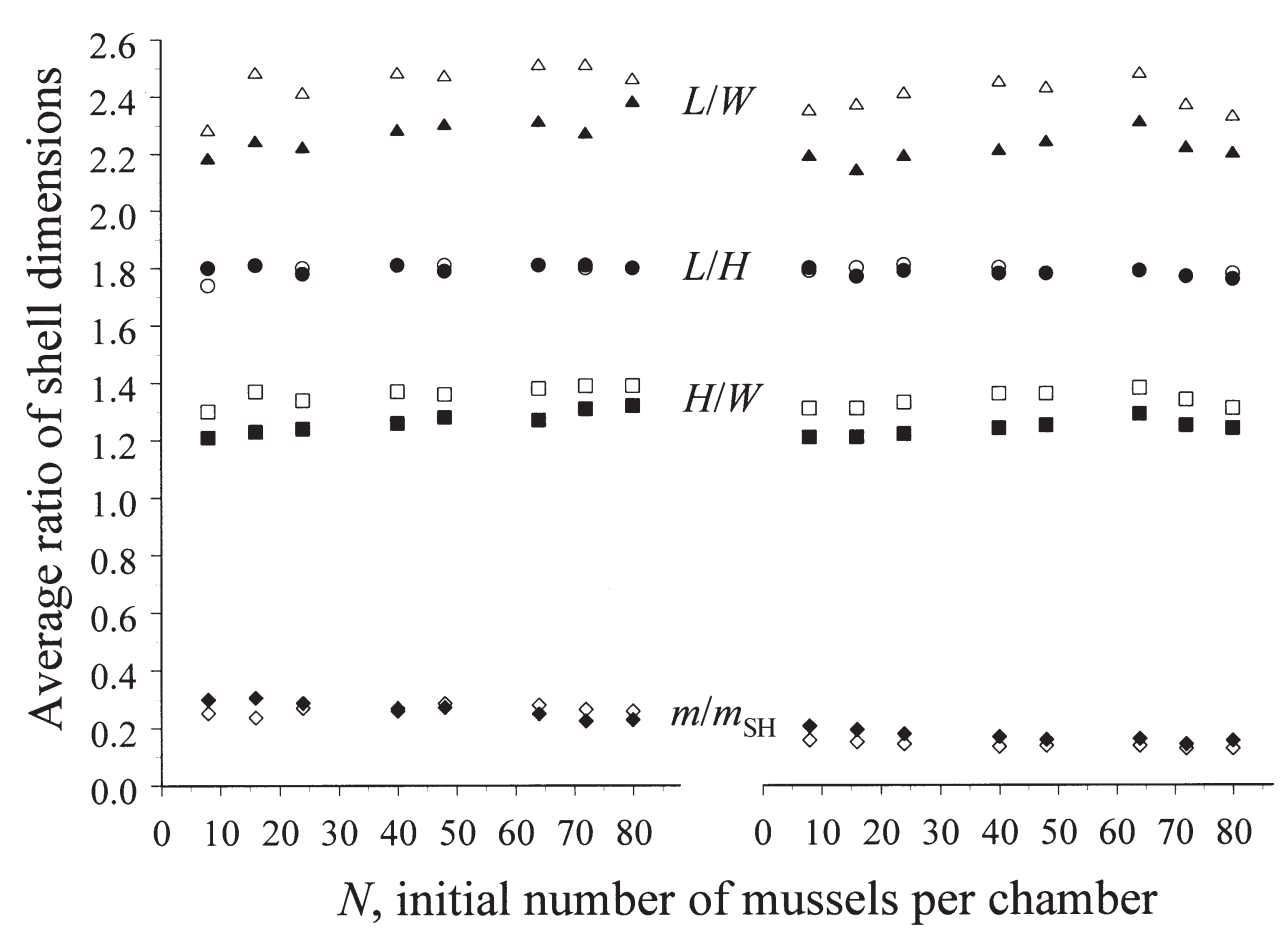

Fig. 1. Mytilus edulis. Average ratios of shell length/height $(L / H)$, length/width $(L / W)$, height/width $(H / W)$, and soft tissue mass/shell mass $\left(\mathrm{m} / \mathrm{m}_{\mathrm{SH}}\right)$ for $M$. edulis reared at 8 different density levels $(N=8,16,24,40,48,64,72$, and 80 mussels per $1 \mathrm{l}$ chamber $)$ and fed under 2 food concentrations (filled symbols, high food; open symbols, low food). Mussels were harvested in October 1995 and October 1996

(Table 2). Multiple a posteriori comparisons indicated that $H / W$ was higher in the LF than in the HF treatment, increased with increasing population density and decreased between 1995 and 1996 (SNK: $\mathrm{p}<0.050$, Fig. 1). Therefore, we conclude that increase in shell width was relatively more restricted than increase in length and that mussels tended to be narrower, i.e. flatter, at high than at low density, and at low than at high food concentration.

Our results show that shell shape was affected by food and density conditions over time. Variations in mussel shell form have been attributed to differences in age, $L / W$ and $H / W$ ratios decreasing with increased shell length (Seed 1968). In our experiment, $L / W$ and $H / W$ decreased between October 1995 and October 1996, indi-

October 1995 and 1996 (Fig. 1). L was approximately 1.8 and 2.3 times greater than $H$ and $W$, respectively. The ratios $L / W$ and $H / W$ increased slightly with increasing population density and were higher in the LF than in the HF treatment, whereas $L / H$ tended to decrease over time (Fig. 1). Multivariate analysis of differences in ln-transformed individual $L / H$ and $L / W$ ratios among treatments showed a significant overall main effect for the food, density and year factors ( $p \ll 0.001$, Table 1$)$. These 3 main effects were independent since none of the interaction terms were statistically significant ( $p>0.05$, Table 1$)$. Univariate results were examined to find out which factor caused changes in shell dimension ratios. The ratio $L / H$ was not affected by food and density ( $p>0.05$, Table 1 ), but apparently exhibited annual variations. The food $\times$ year interaction was marginally significant (Table 1). The ratio $L / W$ was influenced by food and density, but not independently since the food $\times$ density interaction was significant (Table 1, Fig. 1). This indicates a complex response of shell length with regard to width, depending on food and density treatments. $L / W$ changed with year also (Table 1) and was lower in October 1996 than in 1995 (SNK: p < 0.050, Fig. 1). Finally, the separate univariate analysis of the ratio $H / W$ indicated that food, density and year influenced $H / W$ independently cating that age likely affected the shape of mussel shells. $L / H$ is expected to increase with age (Seed 1968). However, our mussels exhibited a decrease in $L / H$ between 1995 and 1996, suggesting that age does not account for all variations in mussel shell shape determined in our experiment. On the other hand, shell form has been shown to be greatly influenced by population density (Seed 1968, 1973, Brown et al. 1976), which is supported by our results. Population density has been advocated to alter shell shape of mussels through competition for food (i.e. exploitative competition; e.g. Seed 1968), but this has never been explicitly demonstrated. Our study, however, clearly establishes that food conditions may influence shell shape among mussel groups of varying density in the laboratory (significant food effect in Table 1). Alternatively, shell distortion was attributed to population density effects through physical compression by surrounding individuals (i.e. interference; e.g. Brown et al. 1976) and was observed in the field in densely packed mussels with higher $L / H$ ratio (i.e. more elongate shells) than mussels in less crowded conditions with more triangular-shaped shells (Seed 1968, 1973, Brown et al. 1976). Severe shell distortion was also reported at extremely high densities in the ribbed mussel, Geukensia demissa (Bertness \& Grosholz 1985). In our experiment, we were not able to resolve whether physical interfer- 
Table 1. Mytilus edulis. MANOVA on ln-transformed individual shell length/height $(L / H)$ and shell length/width $(L / W)$ ratios for mussels held under 2 food concentrations (high food vs low food) and harvested in October 1995 and 1996. Independent variables were food, density and year (fixed factors) and replicate (Rep) nested in the combination of food $\times$ density $\times$ year (Num $\mathrm{df}$ and Den df, numerator and denominator degrees of freedom, respectively; Type III MS and Den MS, numerator and denominator mean squares value, respectively; $F, F$-ratio; $\mathrm{p}>F$, unadjusted probability

\begin{tabular}{|c|c|c|c|c|c|c|}
\hline \multirow[b]{2}{*}{ Source of variation } & \multicolumn{6}{|c|}{ Multivariate analysis of variance } \\
\hline & Num df & Den df & \multicolumn{2}{|c|}{$\begin{array}{l}\text { Wilks' lambda } \\
\text { statistic value }\end{array}$} & $F$ & $\mathrm{p}>F$ \\
\hline Food & 2 & 63 & \multicolumn{2}{|c|}{0.131} & 208.96 & $<0.001$ \\
\hline Density & 14 & 126 & \multicolumn{2}{|c|}{0.236} & 9.53 & $<0.001$ \\
\hline Food $\times$ Density & 14 & 126 & \multicolumn{2}{|c|}{0.748} & 1.40 & 0.160 \\
\hline Year & 2 & 63 & \multicolumn{2}{|c|}{0.602} & 20.78 & $<0.001$ \\
\hline Food $\times$ Year & 2 & 63 & \multicolumn{2}{|c|}{0.952} & 1.60 & 0.210 \\
\hline Density $\times$ Year & 14 & 126 & \multicolumn{2}{|c|}{0.804} & 1.04 & 0.422 \\
\hline Food $\times$ Density $\times$ Year & 14 & 126 & \multicolumn{2}{|c|}{0.834} & 0.85 & 0.609 \\
\hline & \multicolumn{6}{|c|}{ Mixed model analysis of variance } \\
\hline Source of variation & Num df & Den df & Type III MS & Den MS & $F$ & $\mathrm{p}>F$ \\
\hline \multicolumn{7}{|l|}{ Ratio $L / H$} \\
\hline Food & 1 & 119 & 0.002 & 0.003 & 0.67 & 0.416 \\
\hline Density & 7 & 68 & 0.007 & 0.004 & 1.96 & 0.073 \\
\hline Food $\times$ Density & 7 & 68 & 0.004 & 0.004 & 1.04 & 0.412 \\
\hline Year & 1 & 119 & 0.039 & 0.003 & 13.23 & $<0.001$ \\
\hline Food $\times$ Year & 1 & 119 & 0.012 & 0.003 & 3.95 & 0.049 \\
\hline Density $\times$ Year & 7 & 68 & 0.004 & 0.004 & 1.21 & 0.307 \\
\hline Food $\times$ Density $\times$ Year & 7 & 68 & 0.002 & 0.004 & 0.68 & 0.684 \\
\hline Rep $($ Food $\times$ Density $\times$ Year $)$ & r) 64 & 3796 & 0.004 & 0.002 & 1.89 & $<0.001$ \\
\hline \multicolumn{7}{|l|}{ Ratio $L / W$} \\
\hline Food & 1 & 98 & 3.400 & 0.007 & 458.88 & $<0.001$ \\
\hline Density & 7 & 66 & 0.231 & 0.010 & 23.63 & $<0.001$ \\
\hline Food $\times$ Density & 7 & 66 & 0.023 & 0.010 & 2.35 & 0.033 \\
\hline Year & 1 & 98 & 0.428 & 0.007 & 57.71 & $<0.001$ \\
\hline Food $\times$ Year & 1 & 98 & 0.012 & 0.007 & 1.63 & 0.204 \\
\hline Density $\times$ Year & 7 & 66 & 0.015 & 0.010 & 1.49 & 0.187 \\
\hline Food $\times$ Density $\times$ Year & 7 & 66 & 0.004 & 0.010 & 0.39 & 0.906 \\
\hline Rep (Food $\times$ Density $\times$ Year $)$ & r) 64 & 3796 & 0.010 & 0.003 & 2.91 & $<0.001$ \\
\hline
\end{tabular}

Table 2. Mytilus edulis. Four-way mixed ANOVA on ln-transformed individual shell height/ width $(H / W)$ ratio for mussels held under 2 food concentrations (high food vs low food) and harvested in October 1995 and 1996. Independent variables were food, density and year (fixed factors), and replicate (Rep) nested in the combination of food $\times$ density $\times$ year (Num $\mathrm{df}$ and Den df, numerator and denominator degrees of freedom, respectively; Type III MS and Den MS, numerator and denominator mean squares value respectively; $F, F$-ratio; $\mathrm{p}>F$, unadjusted probability

\begin{tabular}{|lrrrrrr|}
\hline Source of variation & Num df & Den df & Type III MS & Den MS & $F$ & $\mathrm{p}>F$ \\
\hline Food & 1 & 119 & 3.238 & 0.006 & 513.34 & $<0.001$ \\
Density & 7 & 68 & 0.181 & 0.008 & 23.67 & $<0.001$ \\
Food $\times$ Density & 7 & 68 & 0.013 & 0.008 & 1.75 & 0.111 \\
Year & 1 & 119 & 0.208 & 0.006 & 32.91 & $<0.001$ \\
Food $\times$ Year & 1 & 119 & $3 \times 10^{-6}$ & 0.006 & 0.00 & 0.984 \\
Density $\times$ Year & 7 & 68 & 0.006 & 0.008 & 0.84 & 0.556 \\
Food $\times$ Density $\times$ Year & 7 & 68 & 0.010 & 0.008 & 1.35 & 0.241 \\
Rep (Food $\times$ Density $\times$ Year) & 64 & 3796 & 0.008 & 0.004 & 1.91 & $<0.001$ \\
\hline
\end{tabular}

ence among mussels contributed to changes in shell shape since the $N$ effects may include both an exploitative and an interference component. The same is likely to occur in field situations. Based on the growing evidence that competition for food is quite frequent in field situations (Fréchette \& Bourget 1985b, Peterson \& Black 1987, Svane \& Ompi 1993, de Montaudouin \& Bachelet 1996), $N$-effects are probably mediated through food availability, but interference cannot be ruled out.

\section{Shell mass growth and comparison with soft tissue growth}

Shell mass $\left(m_{\mathrm{SH}}\right)$ clearly responded to food concentration and population density (Fig. 2). For any given population density, $m_{\mathrm{SH}}$ was much higher at high food than at low food concentration and, irrespective of food treatment, $m_{\mathrm{SH}}$ was lower at high density. Moreover, $m_{\text {SH }}$ increased between October 1995 and 1996 for each food-density level. The relationship between $\ln m_{\mathrm{SH}}$ and $\ln N$ was found to fit a simple linear regression model for density groups, with mortality in both food treatments and years (Fig. 2, Table 3). The slopes were different with respect to both food treatments and years, indicating that the effects of density on shell mass varied in each food treatment over time (Table 3, Fig. 2). We interpret dif- 


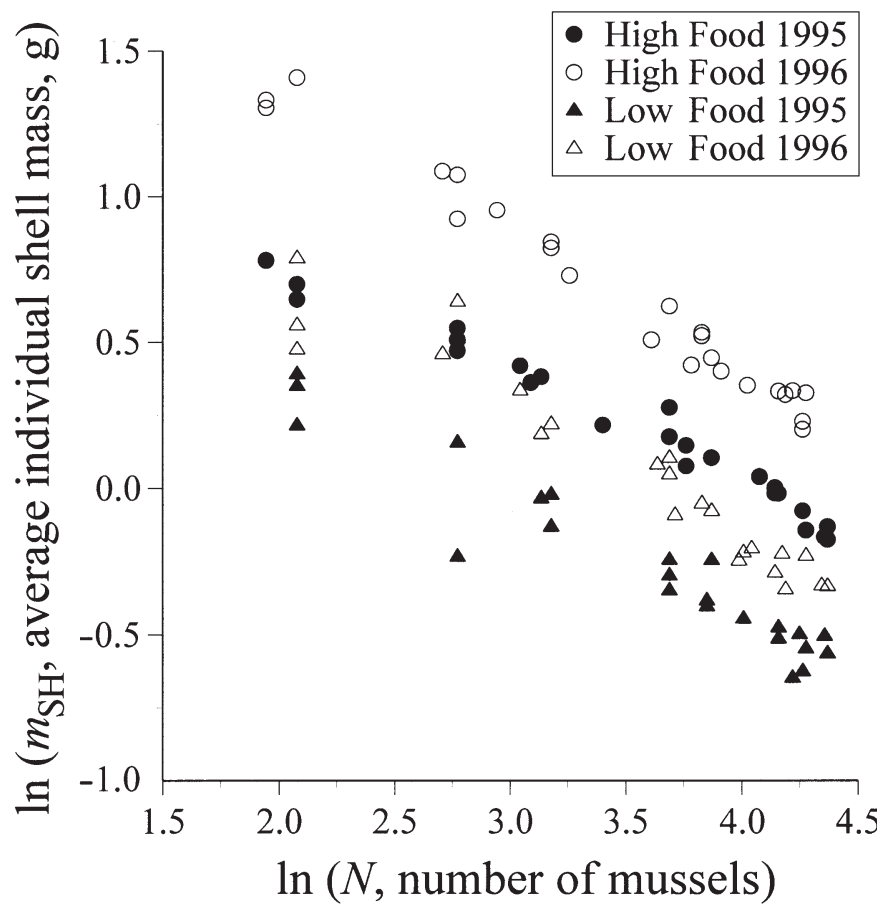

Fig. 2. Mytilus edulis. Scattergram of $\ln N$ (number of mussels per chamber) against $\ln m_{\mathrm{SH}}$ (average individual shell mass per chamber, $g$ ) for $M$. edulis held under 2 experimental conditions, i.e. high food and low food treatments, from December 1994 to October 1996. Mussels were harvested in October 1995 and October 1996

ferences in the slopes as reflecting differences in positive shell growth. In a previous analysis of $m$, no significant changes in soft tissue mass were detected between 1995 and 1996 for any density level, except at N8 in the HF treatment (Alunno-Bruscia et al. 2000). Thus, the $m_{\mathrm{SH}}-N$ curves responded differently than $m$ $N$ curves to varying food concentrations. Mollusks can lose soft tissue mass due to spawning (Bayne \& Worrall

Table 3. Mytilus edulis. Ordinary least square regressions of natural logarithm of average shell mass $\left(m_{\mathrm{SH}}, \mathrm{g}\right)$ against natural logarithm of population density $(N)$ for mussels held under 2 food concentrations (high food vs low food) and harvested in October 1995 and 1996. Only density groups exhibiting mortality were selected. The slopes of significant regressions were compared by analysis of covariance $\left(\mathrm{r}^{2}\right.$, coefficient of determination; $F, F$-statistic; $N_{i}$, sample size; $\left.{ }^{* *} 0.01<\mathrm{p} \leq 0.05 ;{ }^{* * *} \mathrm{p}<0.001\right)$

\begin{tabular}{|llccc|}
\hline Treatment, year & Regression & $\mathrm{r}^{2}$ & $F$ & $N_{i}$ \\
\hline High food, 1995 & $\ln \left(m_{\mathrm{SH}}\right)=-0.414 \cdot \ln (N)+1.680$ & 0.946 & $228.70^{* * *}$ & 15 \\
Low food, 1995 & $\ln \left(m_{\mathrm{SH}}\right)=-0.270 \cdot \ln (N)+0.615$ & 0.687 & $19.74^{* *}$ & 11 \\
High food, 1996 & $\ln \left(m_{\mathrm{SH}}\right)=-0.525 \cdot \ln (N)+2.485$ & 0.958 & $273.87^{* * *}$ & 14 \\
Low food, 1996 & $\ln \left(m_{\mathrm{SH}}\right)=-0.500 \cdot \ln (N)+1.816$ & 0.939 & $169.49^{* * *}$ & 13 \\
& Slope comparison & & $8.42^{* * *}$ & \\
\hline
\end{tabular}

1980, Rodhouse et al. 1984a) or to low food conditions (e.g. Bayne \& Newell 1983), while negative shell growth in marine mollusks has not been reported (but see Downing \& Downing 1993, for a freshwater mussel example).

The soft tissue/shell mass ratio was examined for differences among the food/density levels between October 1995 and 1996. Results of the 4-way mixed ANOVA showed that $\mathrm{m} / \mathrm{m}_{\mathrm{SH}}$ differed significantly between food treatments, density groups and years (Fig. 1, Table 4). The ratio $\mathrm{m} / \mathrm{m}_{\mathrm{SH}}$ was significantly lower in October 1996 (1:7) than in October 1995 (1:5), lower in the LF than in the HF treatment, and lower at high than at low density (SNK: $\mathrm{p}<0.05$, Fig. 1). Thus, the mussels growing at high density and in the LF regime had a relatively lower condition index (flesh dry mass/shell mass ratio) than those kept at low density or in the HF treatment. Mussels apparently responded to greater food competition in the LF treatment or at high density by reducing $(N 8)$ or ceasing $(N 16$ to $N 80)$ absolute tissue growth, but not absolute shell mass growth. Differences in mass gain and resource allocation between flesh and shell have been ascribed to differences in habitat (subtidal vs intertidal: e.g. Rao 1953, Seed 1973, Brown \& Seed 1977, Aldrich \& Crowley 1986), ecosystem (inshore vs open ocean: Barkati \& Choudhry 1988), culture methods (Hickman \& Illingworth 1980, Barkati \& Ahmed 1994) or variations in environmental conditions such as food availability, degree of pollution, water temperature, salinity and wave exposure (e.g. Raubenheimer \& Cook 1990, Akester \& Martel 1999). We conclude that mussels invest differentially in shell material relative to soft tissue in response to $N$-effects, which reflected food depletion although interference cannot be ruled out.

Materials for production of bivalve shell and soft tissue originate partly from different sources. Changes in soft tissue mass are typically driven by seasonal variation in food availability (Widdows et al. 1979, Bayne \& Newell 1983, Page \& Hubbard 1987), mechanisms of energy storage and utilization (Gabbott 1976, Rodhouse et al. 1984b, Peterson \& Fegley 1986), and the reproductive cycle (Bayne \& Worrall 1980). On the other hand, the shell is formed largely through deposition of ions, mostly calcium from the seawater (Wilbur \& Saleuddin 1983), and has a much lower organic content $(<5 \%)$ than soft tissue (Jørgensen 1976, Price et al. 1976). Thus, shell growth may be only partially dependent on metabolic carbon (Tanaka et al. 1986), and may be less susceptible to variability in food availability than tissue growth because 
of the constant presence of dissolved calcium in seawater. There are many reports indicating that shell production in several species of marine invertebrates continued in the absence of feeding (e.g. Palmer 1981) and that shell growth still occurred in undernourished or starved mollusks (Orton 1925, Pannella \& MacClintock 1968, Thompson 1975, Strömgren \& Cary 1984), even when tissue growth was negative (Lewis \& Cerrato 1997). This might reflect a strategy to increase the habitable volume of shells in anticipation of future soft tissue growth (Palmer 1981).

\section{Shell length-body mass-population density relationships}

\section{Chambers with mortality}

The response of mussels to food and density was also studied by examining their tridimensional lengthmass-density relationships, firstly by selecting food- density treatments exhibiting mortality. Multiple regression analysis revealed that the independent variables (i.e. shell length, density, food and year) accounted respectively for $87 \%$ and $94 \%$ of the variance in $\ln m$ and $\ln m_{\mathrm{SH}}$ (Table 5). The highest contribution to the variance in Eq. (1) for $\ln m$ and $\ln m_{\mathrm{SH}}$ was attributable to shell length (lnm: $F=1624.63, \ln m_{\mathrm{SH}}$ : $F=2995.12, \mathrm{p} \ll 0.001$ in both cases), followed by food (lnm: $F=27.08, \ln m_{\mathrm{SH}}: F=40.28, \mathrm{p} \ll 0.001$ in both cases), and year $\left(\ln m: F=5.68, \mathrm{p}=0.017 ; \ln m_{\mathrm{SH}}: F=\right.$ 26.07, $\mathrm{p} \ll 0.001)$. Population density contributed significantly to Eq. (1) for $\ln m(F=5.47, \mathrm{p}=0.019)$, but not for $\ln m_{\mathrm{SH}}(F=0.09, \mathrm{p}=0.766)$. The effects of food and density on the $L-m-N$ relationship did not vary between years (year $x$ food interaction: $F=0.45, \mathrm{p}=0.505$; year $\times$ density interaction: $F=0.31$, $\mathrm{p}=0.579$ ). There were, however, interannual variations in the effects of food (year $\times$ food interaction: $F=$ 69.78, $\mathrm{p} \ll 0.001$ ) and population density (year $\times$ density interaction: $F=9.65, \mathrm{p}=0.002)$ on the $L-m_{\mathrm{SH}^{-}} N$ relationship.

The tridimensional length-massdensity relationships were analyzed first by comparing elevations between food treatments and years (Table 5). With $\ln m$ or $\ln m_{\mathrm{SH}}$ as the dependent variable, elevations were significantly different between food treatments $\left(\beta_{3} \neq 0, t=5.20\right.$, $\mathrm{p} \ll 0.001)$. A decline in food availability resulted in a decrease of the intercept of the length-mass-density relationship for both $\ln m$ or $\ln m_{\mathrm{SH}}$ (Table 5). Elevations, however, increased over time $\left(\beta_{4} \neq 0\right.$, 
$t=-2.38, \mathrm{p} \leq 0.017 ;$ Table 5). This indicates that, for a given shell length and population density, soft tissue and shell mass were lower in the LF than in the HF treatment, and $m$ and $m_{\mathrm{SH}}$ were higher in October 1996 than in October 1995.

Secondly, we examined the slopes of the relationships of $\ln m$ or $\ln m_{\mathrm{SH}}$ against $\ln L$ and $\ln N$ (Table 5). The slope of the $\ln L-\ln m$ relationship did not differ significantly between food treatments $\left(\beta_{5}\right.$ not $\neq 0$, $t=-1.91, \mathrm{p}=0.065$ ), but varied between October 1995 and 1996 in each food treatment $\left(\beta_{7} \neq 0, t=-2.28\right.$, $\mathrm{p}<0.050)$. The $\ln L-\ln m$ slope was significantly $>3$ at both low food and high food levels ( $p \ll 0.001$ ), suggesting positive allometry. The classical ontogenetic interpretation for this allometric exponent is that mussels grew relatively faster in $m$ than in $L$. The $L-m-N$ relationship, however, was computed from pooled samples of mussels that have been subjected to different density treatments. Thus, the relationship between $m$ and $L$ varied because of $N$-effects, in addition to physiological constraints driving ontogenetic allometry. We interpret positive allometry as indicating that growth in shell length was less depressed by density than soft tissue growth resulting in large mussels (i.e. in low density groups) with relatively higher $m$ than small mussels (i.e. in high density groups; Table 4). This shell length-body mass relationship with a slope $>3$ may also be related to changes in shell shape. Due to their relative 'flatness' at high density and at low food, mussels are expected to have a relatively smaller habitable volume of shell and a lower soft tissue mass than at low density and at high food. The difference in relative growth between large and small mussels decreased between October 1995 and 1996 since the $\ln L-\ln m$ slope was steeper in 1995 than in 1996 (Table 5). On the other hand, the slopes of the $\ln L$ $\ln m_{\mathrm{SH}}$ relationship did not differ significantly between food treatments $\left(\beta_{5}\right.$ not $\left.\neq 0, t=-1.78, \mathrm{p}=0.075\right)$ or years $\left(\beta_{7}\right.$ not $\left.\neq 0, t=0.91, P=0.364\right)$, and were $<3$, suggesting that small mussels had relatively heavier shells than large mussels. This is supported by the changes observed for the $m / m_{\mathrm{SH}}$ ratio, which decreased with increasing $N$ (Fig. 1, Table 4). In summary, the slopes of the $\ln L-\ln m$ and $\ln L-\ln m_{\mathrm{SH}}$ relationships did not differ between food treatments and were consistent with allometric growth, positive for $m$ and negative for $m_{\mathrm{SH}}$.

Soft tissue and shell mass of the mussels decreased with increasing densities as shown by the negative slopes of the $\ln N-\ln m$ and $\ln N-\ln m_{\mathrm{SH}}$ relationships (Table 5). However, $m$ and $m_{\mathrm{SH}}$ responded differently to population density. For the soft tissue mass, the $\ln N$ $\ln m$ slope did not vary significantly between years $\left(\beta_{8}\right.$ not $\left.\neq 0, t=-0.55, \mathrm{p}=0.579\right)$ or between food treatments $\left(\beta_{6}\right.$ not $\left.\neq 0, t=-1.42, p=0.156\right)$. Therefore, the negative effects of population density on $m$ were com- parable for both food treatments over time (Table 5). For $m_{\mathrm{SH}}$, however, the effects of density differed significantly between years $\left(\beta_{8} \neq 0, t=-3.11, \mathrm{p}=0.002\right)$, the slope of the $\ln N-\ln m_{\mathrm{SH}}$ relationship being steeper in October 1996 than in October 1995 in each food treatment (Table 5). The effects of density on $m_{\mathrm{SH}}$ were more pronounced at high food than at low food $\left(\beta_{6} \neq 0\right.$, $t=-2.19, \mathrm{p}=0.029$; Table 5). This result is congruent with the comparison of significant regressions of $\operatorname{lnm}_{\mathrm{SH}}$ against $\ln N$ between food treatments and years, which indicated heterogeneity of the regression slopes (Fig. 2, Table 3).

In summary, we found that for groups of mussels exhibiting mortality a decrease in food availability resulted in a decrease of the intercept of the shell length-body mass-population density relationship, without significant changes in the slope of the shell lengthbody mass (soft tissue and shell) relationship (Table 5). Therefore, mussels had their condition index reduced, but independently of their shell length, that is, of the density group (which directly affects $L$ ), suggesting that competition was symmetric among food-density treatments (see also Alunno-Bruscia et al. 2000, for further evidence of symmetric competition in mussel groups with mortality). Symmetry in competitive abilities of mussels implies that individuals exhibited equal efficiency in exploiting the available food in both HF and LF treatments. Thus, physiological behavior is expected to be homogeneous among density groups with mortality.

\section{The whole set of 11 chambers}

For all chambers, elevations of the tridimensional length-body mass-density relationships differed over food-year combinations (Table 5). Elevations decreased at low food $\left(\beta_{3} \neq 0, t=7.95, \mathrm{p}<0.001\right)$ and increased over time $\left(\beta_{4} \neq 0, t=-2.87, \mathrm{p}<0.010\right)$, thus following the same tendency as for groups of mussels with mortality (Table 5). Therefore, condition index of mussels diminished with decreasing food availability.

We examined growth in $m$ and $m_{\mathrm{SH}}$ relative to $L$ (Fig. 3, Table 5). The slope of the $\ln L-\ln m$ relationship was $>3$ for the LF treatment in October 1995 and 1996, and for the HF treatment in October 1995 only ( $\mathrm{p} \ll 0.001)$, indicating positive allometry. Thus, as in 11 chambers with mortality, large mussels (in low density groups) were relatively heavier than small mussels (in high density groups), since soft tissue growth was relatively more affected by density treatment than shell length. In October 1996, however, growth in $m$ was isometric at high food $(F=0.71, \mathrm{p}=0.399$; Table 5$)$. Conversely, the slope of the $\ln L-\ln m_{\mathrm{SH}}$ relationship was $<3$, indicating that small mussels exhibited rela- 
tively heavier shells than large individuals. These differences in relative growth in $m$ and $m_{\mathrm{SH}}$ between small and large mussels were more pronounced in the LF than in the HF treatment since both $\ln L-\ln m$ and $\ln L-\ln m_{\mathrm{SH}}$ slopes were steeper at low food than at high food (Table 5). Thus, a decrease in food availability resulted in a significant increase in the slope of the shell length-body mass for mussels from all $11 \mathrm{cham}$ bers as opposed to the situation in which only chambers with mortality were considered (Table 5). To account for increasing slope of the $\ln L-\ln m$ relationship with decreasing food level, let us consider a hypothetical situation in which an $L-m-N$ relationship would be obtained from different mussel groups or
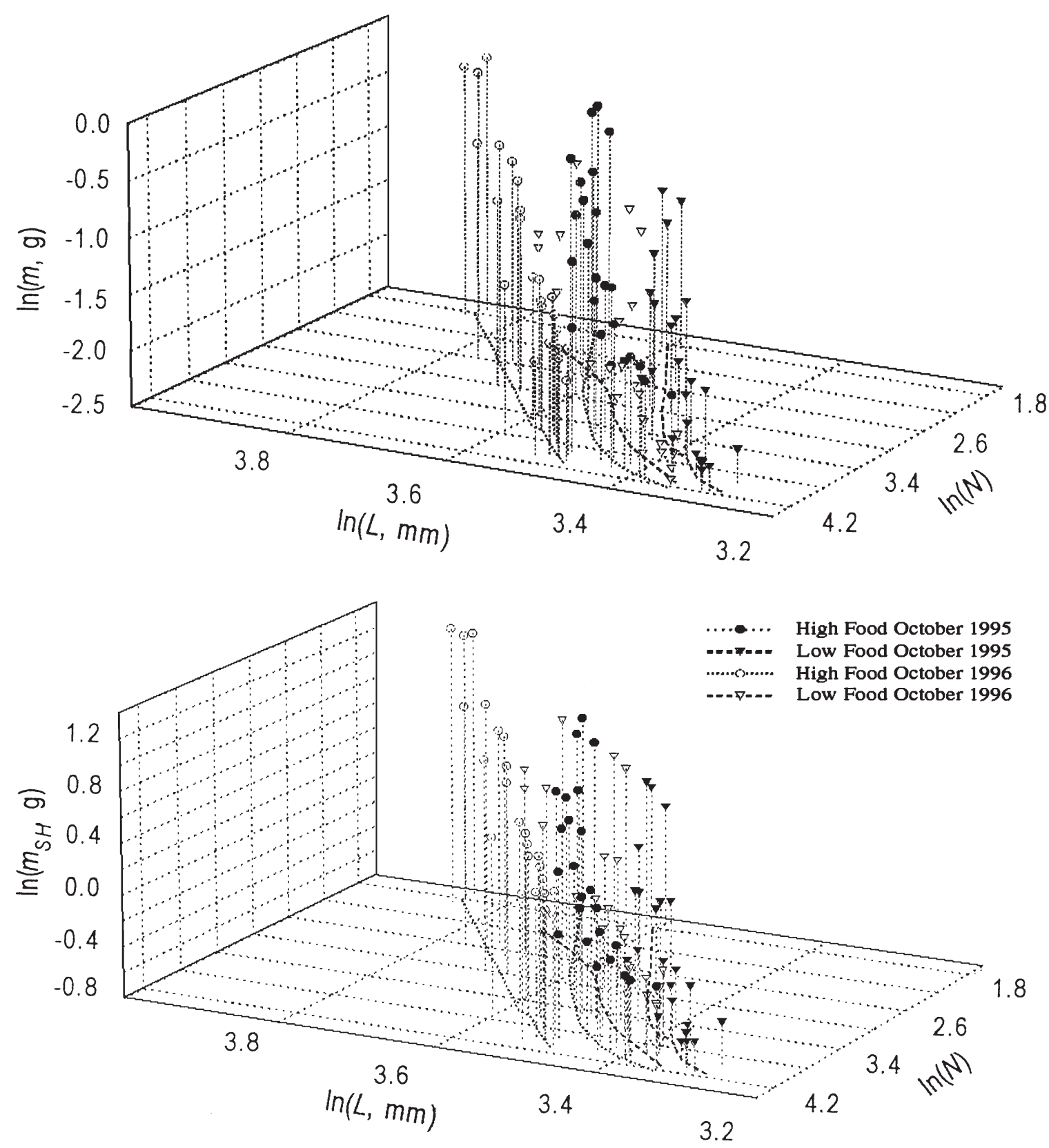

Fig. 3. Mytilus edulis. Tridimensional plots of $\ln m$ (ash-free dry mass, g) (upper panel) or $\ln m_{\mathrm{SH}}$ (shell mass, g) (lower panel) against $\ln L$ (shell length) and $\ln N_{\mathrm{F}}$ (final density of mussels per chamber) for high food and low food treatments in October 1995 (open symbols) and October 1996 (filled symbols). Multiple regression models were based on individual observations $(N=3895$ mussels) among all food-density treatments. For clarity, average points at each food-density level only are represented. Sinuous broken lines projected onto the horizontal plane represent the average adjusted models 
patches with no competition. Adding groups experiencing food regulation, i.e. with low condition index and reduced $L$ (like in the present experiment), to the first set would result in tipping the slope of the lengthmass relationship to higher values. The same result is expected in situations where a size-dependent component to food regulation results from space limitation, as when $N$-effects interfere with normal feeding inversely to mussel size (Fréchette \& Despland 1999). Therefore, length-mass relationships with a high slope $>3$ may be obtained in situations where regulating factors are quite different. Since the length-mass-density relationship plays a central role in the prediction of selfthinning slopes (Fréchette \& Lefaivre 1990, Fréchette et al. 1992), such situations impose a major limitation in the use of self-thinning relationships for resolving factors, space or food, regulating growth.

The effects of population density on $m$ and $m_{\mathrm{SH}}$ growth were negative in both food regimes (Table 5). No interannual change in the density effects on $m$ was recorded ( $\beta_{8}$ not $\left.\neq 0, t=-1.28, \mathrm{p}=0.199\right)$, but the slope was steeper in high food than in low food regimes $\left(\beta_{6} \neq 0, t=-3.27, \mathrm{p}=0.048\right.$; Table 5$)$. Thus, population density apparently did not affect $m$ with the same intensity in the HF treatment as in the LF treatment. This is congruent with results from a related analysis on the same data whereby $m$ increased between October 1995 and October 1996 at N8 in the HF treatment but it remained constant for other density groups and even slightly decreased at high density (Fig. 4 in Alunno-Bruscia et al. 2000). Finally, the effects of population density on $m_{\mathrm{SH}}$ were not significantly different among food treatments $\left(\beta_{6}\right.$ not $\left.\neq 0, t=-0.12, \mathrm{p}=0.904\right)$, but were significantly stronger in October 1995 than in October 1996 in each food regime $\left(\beta_{8} \neq 0, t=-3.07\right.$, $\mathrm{p}=0.002$; Table 5).

For the whole set of growth chambers, we observed that a decrease in food availability resulted in a decrease of the intercept of the shell length-body mass-population density relationship, but with significant changes in the slope of the shell length-body mass (soft tissue and shell) relationship (Table 5). Thus, contrary to the analysis restricted to groups of mussels exhibiting mortality, the resulting decrease in mussel condition index was inversely dependent on shell length, that is, on density group, thus implying an apparent asymmetry in competition for food. This effect, however, was not consistent with true asymmetry, resulting in a disproportionate advantage in growth for large individuals over small ones (Weiner 1990). In the analysis of the $L-m-N$ relationship, chambers were pooled together. Thus, apparent asymmetry in competition between food levels reflected differences in feeding abilities and in growth capacities of mussels among food-density treatments. Clearly, apparent asymmetry resulted in the same response of the length-mass relationship as asymmetric competition, although different underlying mechanisms may be involved. It is thus important to interpret length-massdensity relationships carefully when pooling groups of mussels experiencing different levels of competition since the same response may arise from different causes.

In conclusion, our study shows that narrow shells do not necessarily imply interference or space competition in mussel beds. Actually, we were not able to demonstrate interference competition, whereas food regulation effects were severe and shells grew narrower. In addition, the length-mass-density relationship of Mytilus edulis from all experimental $1 \mathrm{l}$ chambers exhibited complex responses to food level. Such responses are likely also to occur in field situations, where a priori knowledge of the occurrence of mortality is not possible. Furthermore, downstream food depletion above bivalve beds (Fréchette et al. 1989) may act like our different food-density treatments by locally modifying the severity of competition (Newell 1990). Thus, spatial variability in the severity of fooddriven competition in the field may blur the $L-m-N$ relationship, making prediction of self-thinning curves uncertain. Our study casts doubt on the use of shell length-body mass relationships for detecting and interpreting asymmetric competition from field samples, and for using self-thinning curves to infer the nature of the regulating factor. In the case of organisms such as mussels, a further difficulty in predicting self-thinning is the effect of multi-layering of individuals (Guiñez \& Castilla 1999).

Acknowledgements. We are grateful to L. Girard, J. Quimper, S. Brulotte, P. Goudreau, D. Dransart, C. Forget, J. Hamel, C. Mékhadoun, L. Pagé, F. Seguin, E. Deloison, B. Chenard, J. Gagnon, G. Jean and M. Valois for their help in the field and laboratory. We thank G. Daigle (Service de Consultation Statistique, Département de Mathématiques et de Statistique, Universite Laval) for assistance with statistical analyses. We are grateful to P. Petraitis, C. Bacher and 3 anonymous reviewers for helpful comments. M. Alunno-Bruscia was supported by funding from DFO (Department of Fisheries and Oceans Canada), GIROQ (Groupe Interuniversitaire de Recherches Océanographiques du Québec) and Université Laval.

\section{LITERATURE CITED}

Akester RJ, Martel AL (1999) Shell shape, dysodont tooth morphology, and hinge-ligament thickness in the bay mussel Mytilus trossulus correlate with wave exposure. Can J Zool 78:240-253

Aldrich JC, Crowley M (1986) Condition and variability in Mytilus edulis (L.) from different habitats in Ireland. Aquaculture 52:273-286

Alunno-Bruscia M, Petraitis P, Bourget E, Fréchette M (2000) 
Body-size density relationship for Mytilus edulis in an experimental food-regulated situation. Oikos 90:28-42

Banavar JR, Maritan A, Rinaldo A (1999) Size and form in efficient transportation networks. Nature 399:130-132

Barkati S, Ahmed M (1994) Seasonal variation in condition index of Mytilus edulis from Lindaspollene, Norway. Mar Res Karachi 3:33-45

Barkati S, Choudhry Y (1988) Effect of tidal height on growth of mussels. Pak J Sci Ind Res 31:415-422

Bayne BL, Newell RC (1983) Physiological energetics of marine molluscs. In: Saleuddin ASM, Wilbur KM (eds) The Mollusca. Academic Press, New York, p 407-515

Bayne BL, Worrall CM (1980) Growth and production of mussels Mytilus edulis from two populations. Mar Ecol Prog Ser 3:317-328

Bertness MD, Grosholz E (1985) Population dynamics of the ribbed mussel, Geukensia demissa: the costs and benefits of an aggregated distribution. Oecologia (Berl) 67: 192-204

Bertness MD, Gaines SD, Yeh SM (1998) Making mountains out of barnacles: the dynamics of acorn barnacle hummocking. Ecology 79:1382-1394

Brown RA, Seed R (1977) Modiolus modiolus - an autecological study. In: Keegan BF, O'Ceidigh P, Boaden PJS (eds) Proc 11th Eur Mar Biol Symp, Pergamon Press, Oxford, p 93-100

Brown RA, Seed R, O'Connor J (1976) A comparison of relative growth in Cerastoderma (= Cardium) edule, Modiolus modiolus, and Mytilus edulis (Mollusca: Bivalvia). J Zool (Lond) 179:297-315

Chinzei K, Savazzi E, Seilacher A (1982) Adaptional strategies of bivalves living as infaunal secondary soft bottom dwellers. Neues Jahrb Geol Paleaontol Abh 164:229-244

Cigarria J, Fernandez J (1998) Manila clam (Ruditapes philippinarum) culture in oyster bag: influence of density on survival, growth and biometric relationships. J Mar Biol Assoc UK 78:551-560

Coe WR (1946) Nutrition and growth of the California baymussel (Mytilus edulis diegensis). J Exp Zool 99:1-14

Demers S, Therriault J-C, Bourget E, Bah A (1987) Resuspension in the shallow sublittoral zone of macrotidal estuarine environment: wind influence. Limnol Oceanogr 32: 327-339

de Montaudouin X, Bachelet G (1996) Experimental evidence of complex interactions between biotic and abiotic factors in the dynamics of an intertidal population of the bivalve Cerastoderma edule. Oceanol Acta 19:449-463

Downing WL, Downing JA (1993) Molluscan shell growth and loss. Nature 362:506

Fréchette M, Bourget E (1985a) Energy flow between the pelagic and benthic zones: factors controlling particulate organic matter available to an intertidal mussel bed. Can J Fish Aquat Sci 42:1158-1165

Fréchette $M$, Bourget $E$ (1985b) Food-limited growth of Mytilus edulis L. in relation to the benthic boundary layer. Can J Fish Aquat Sci 42:1166-1170

Fréchette M, Despland E (1999) Impaired shell gaping and food depletion as mechanisms of asymmetric competition in mussels. Ecoscience 6:1-11

Fréchette M, Grant J (1991) An in situ estimation of the effect of wind-driven resuspension on the growth of the mussel Mytilus edulis L. J Exp Mar Biol Ecol 148:201-213

Fréchette M, Lefaivre D (1990) Discriminating between food and space limitation in benthic suspension feeders using self-thinning relationships. Mar Ecol Prog Ser 65:15-23

Fréchette M, Butman CA, Geyer WR (1989) The importance of boundary-layer flows in supplying phytoplankton to the benthic suspension feeder, Mytilus edulis L. Limnol Oceanogr 34:19-36

Fréchette M, Aitken AE, Pagé L (1992) Interdependence of food and space limitation of a benthic suspension feeder: consequences for self-thinning relationships. Mar Ecol Prog Ser 83:55-62

Gabbott PA (1976) Energy metabolism. In: Bayne BL (ed) Marine mussels: their ecology and physiology. Cambridge University Press, Cambridge, p 293-355

Guiñez R, Castilla JC (1999) A tridimensional self-thinning model for multilayered intertidal mussels. Am Nat 154:341-357

Hand DJ, Taylor CC (1987) Multivariate analysis of variance and repeated measures. Chapman \& Hall, New York

Hickman RW, Illingworth J (1980) Condition cycle of the green-lipped mussel Perna canaliculus in New Zealand. Mar Biol 60:27-38

Jorgensen CB (1976) Growth efficiencies and factors controlling size in some mytilid bivalves, especially Mytilus edulis L.: review and interpretation. Ophelia 15:175-192

Kranck K (1979) Dynamics and distribution of suspended particulate matter in the St. Lawrence Estuary. Nat Can (Que) 106:163-173

LaBarbera M (1989) Analysing body size as a factor in ecology and evolution. Annu Rev Ecol Syst 20:97-117

Lent CM (1967) Effect of habitat on growth indices in the ribbed mussel, Modiolus (Arcuatula) demissus. Chesapeake Sci 8:221-227

Lewis DE, Cerrato RM (1997) Growth uncoupling and the relationship between shell growth and metabolism in the soft shell clam Mya arenaria. Mar Ecol Prog Ser 158: $177-189$

Neter J, Wasserman W, Kutner MH (1985) Applied linear statistical models. Irwin, New York

Newell CR (1990) The effects of mussel (Mytilus edulis Linnaeus, 1758) position in seeded bottom patches on growth on subtidal lease sites in Maine. J Shellfish Res 9:113-118

Ohba S (1956) Effects of population density on mortality and growth in an experimental culture of bivalve, Venerupis semidecussata. Biol J Okayama Univ 2:169-173

Okamura B (1986) Group living and the effects of spatial position in aggregations of Mytilus edulis. Oecologia (Berl) 69: 341-347

Orton JH (1925) The conditions for calcareous metabolism in oysters and other marine animals. Nature 116:13

Page HM, Hubbard DM (1987) Temporal and spatial patterns of growth in mussels Mytilus edulis on an offshore platform: relationships to water temperature and food availability. J Exp Mar Biol Ecol 111:159-179

Paine RT, Suchanek TH (1983) Convergence of ecological processes between independently evolved competitive dominants: a tunicate-mussel comparison. Evolution 37: 821-831

Palmer AR (1981) Do carbonate skeletons limit the rate of body growth? Nature 292:150-152

Pannella G, MacClintock C (1968) Biological and environmental rhythms reflected in molluscan shell growth. Paleontol Soc Mem 2:64-79

Peters RH (1983) The ecological implications of body size. Cambridge University Press, Cambridge

Peterson CH (1982) The importance of predation and intraand interspecific competition in the population biology of two infaunal suspension-feeding bivalves, Protothaca staminea and Chione undatella. Ecol Monogr 52:437-475

Peterson CH, Black R (1987) Resource depletion by active suspension feeders on tidal flats: influence of local density and tidal elevation. Limnol Oceanogr 32:143-166 
Peterson CH, Fegley SR (1986) Seasonal allocation of resources to growth of shell, soma, and gonads in Mercenaria mercenaria. Biol Bull (Woods Hole) 171:597-610

Price TJ, Thayer GW, La Croix MW, Montgomery GP (1976) The organic content of shells and soft tissues of selected estuarine gastropods and pelecypods. Proc Natl Shellfish Assoc 65:26-31

Rao KP (1953) Shell weight as a function of intertidal height in a littoral population of pelecypods. Experentia 9:465-466

Raubenheimer D, Cook P (1990) Effects of exposure to wave action on allocation of resources to shell and meat growth by the subtidal mussel, Mytilus californianus. J Shellfish Res 9:87-93

Richardson CA, Seed R (1990) Predictions of mussel (Mytilus edulis) biomass on an offshore platform from single population samples. Biofouling 2:289-297

Rodhouse PG, Roden CM, Burnell GM, Hensey MP, McMahon T, Ottway B, Ryan TH (1984a) Food resource, gametogenesis and growth of Mytilus edulis on the shore and in suspended culture: Killary Harbour, Ireland. J Mar Biol Assoc UK 64:513-529

Rodhouse PG, Roden CM, Hensey MP, Ryan TH (1984b) Resource allocation in Mytilus edulis on the shore and in suspended culture. Mar Biol 84:27-34

SAS (1989) SAS/STAT user's guide, Release 6.04 edn. SAS Instutute, Cary, NC

Schepartz B (1980) Dimensional analysis in the biomedical sciences. Thomas CC, Springfield

Seed R (1968) Factors influencing shell shape in the mussel Mytilus edulis. J Mar Biol Assoc UK 48:561-584

Seed R (1973) Absolute and allometric growth in the mussel, Mytilus edulis L. (Mollusca Bivalvia). Proc Malacol Soc Lond 40:343-357

Seed R (1980) Shell growth and form in Bivalvia. In: Rhoads DC, Lutz RA (eds) Skeletal growth of aquatic organisms.

Editorial responsibility: Otto Kinne (Editor),

Oldendorf/Luhe, Germany
Plenum Press, New York, p 23-67

Sokal RR, Rohlf FJ (1981) Biometry, 3rd edn. Freeman, San Francisco

Stevens J (1992) Applied multivariate statistics for the social sciences, 3rd ed. Lawrence Erlbaum Associates, Hillsdale

Strömgren T, Cary C (1984) Growth in length of Mytilus edulis L. fed on different algal diets. J Mar Biol Assoc UK 76:23-34

Svane I, Ompi M (1993) Patch dynamics in beds of the blue mussel Mytilus edulis L.: effects of site, patch size, and position within a patch. Ophelia 37:187-202

Tanaka N, Monaghan M, Rye DM (1986) Contribution of metabolic carbon to mollusc and barnacle shell carbonate. Nature 320:520-523

Tanita S, Kikuchi S (1957) On the density effect of the raft cultured oysters. I. The density effect within one plate. Bull Tohoku Reg Fish Lab Res 9:133-142

Thompson I (1975) Biological clocks and shell growth in bivalves. In: Rosenberg GD, Runcorn SK (eds) Growth rhythms and the history of the earth's rotation. John Wiley \& Sons, London, $\mathrm{p}$ 149-161

Weiner J (1990) Asymmetric competition in plant populations. Trends Ecol Evol 5:360-364

West GB, Brown JH, Enquist BJ (1997) A general model for the origin of allometric scaling laws in biology. Science 276:122-126

Widdows J, Fieth P, Worrall CM (1979) Relationships between seston, available food and feeding activity in the common mussel Mytilus edulis. Mar Biol 50:195-207

Wilbur KM, Saleuddin ASM (1983) Shell formation. In: Saleuddin ASM, Wilbur KM (eds) The Mollusca, Vol. 4, Physiology, Part 1. Academic Press, New York, p 235-287

Wildish DJ, Kristmanson DD (1984) Importance to mussels of the benthic boundary layer. Can J Fish Aquat Sci 41: 1618-1625

Submitted: October 7, 1999; Accepted: January 17, 2001 Proofs received from author(s): August 10, 2001 